\title{
Millennium Development Goals: progress in Oceania
}

\author{
John D Vince
}

Correspondence to

Dr John D Vince, Clinical Sciences Division, School of Medicine and Health Sciences, University of Papua New Guinea, PO Box 5623, Boroko, National Capital District, Port Moresby 111, Papua New Guinea; johndvince@gmail. com

Received 16 April 2014 Revised 20 May 2014 Accepted 24 May 2014
For the purposes of this commentary, Oceania is understood to encompass the Pacific Island states of Micronesia, Polynesia and Melanesia including Papua New Guinea (PNG) (but excluding the western half of mainland New Guinea, politically a province of Indonesia), Timor Leste, Australia and New Zealand. In geopolitical Oceania (which excludes Timor Leste), 25 countries, 12 with a population $<100000$, are scattered over an area of $8525989 \mathrm{~km}^{2}$ (figure 1). The total population is $35670000,27.5$ million of whom are in Australia and New Zealand. PNG accounts for the large majority of the remainder. The great majority of the population in Australia and New Zealand are urban dwellers, while the majority of the population in the other countries is rural, the people often living in villages with very difficult access on small islands or atolls or in remote mountain ranges.

The region includes countries with widely differing economies, infrastructure development, education, health service provision, and health indices. Table 1, based on data from Unicef's State of the World's Children and the United Nations Development Programme reports, indicates some of the important indices relating to child health from a selection of the countries. ${ }^{1} 2$ Only one country, Timor Leste, had reached the Millennium Development Goal (MDG)-4 target by 2012, but from a very high under 5 mortality rate in 1990 . Australia, New Zealand and Vanuatu may reach the target, but most of the countries are unlikely to do so.

Mortality rates and economic indicators in Australia and New Zealand are similar to those throughout the rest of the Organization for Economic Cooperation and Development (OECD) countries. However, the overall figures mask, as they do in most countries, mortality rates for their disadvantaged population: in the case of Australia, the Aboriginal and Torres Strait Island population, which are more than double the national figures. Nevertheless, mortality rates in this population have been reduced by almost $50 \%$ since $2002 .{ }^{3}$

Good child health is dependent on many interrelated factors, the most important of which are living conditions, the level of female literacy, and financing for, provision of, and accessibility to preventative and curative health services. Between 2007 and 2011, the proportion of the gross national product allocated to health varied from $3 \%$ in PNG and Fiji to $14 \%$ in Kiribati, with the majority of countries in the $5-8 \%$ range. In PNG, this translates to US\$35-40\$ per capita.

Almost all the countries with low mortality have near $100 \%$ primary education, with many having high levels of secondary and tertiary education. Countries with higher mortality have poorer education levels, and even then the figures hide important gender disparities. There is often a higher proportion of male than female children enrolled, and girls are less likely than boys to complete primary education. The standard of primary education in a city school in Australia with state-of-the-art internet technology is vastly different from that in a remote village school in PNG, Solomon Islands or Vanuatu, where books and blackboards may be non-existent.

Maternal mortality rates in some of the countries are high, and in PNG, where only 52\% of women deliver in health facilities, and in Timor Leste, the rates are alarmingly high. Neonatal mortality rates are correspondingly high, accounting for $50 \%$ of infant mortality. The common causes of neonatal death are infection, birth asphyxia and problems associated with low birth weight. The death of a mother puts her child at risk not only of neonatal but also of later infant and child mortality.

Transport systems to provide ready access to health services are essential. However, in many of the smaller island countries, transport is by dinghy or air. In the larger islands, road transport may simply not exist in some areas, and access is either by air to small airstrips or by foot. Where there are roads, they are likely to be unmetalled and at times unusable by vehicles. Security concerns may also hamper the delivery of services in some countries and some areas. Unfortunately, run down, inadequately staffed and inadequately supplied health facilities are common in some of the countries in the region, preventing health service delivery even when access is possible.

For some of the region's countries such as PNG, Solomon Islands and Vanuatu, population growth rates of $>2.4 \%$ pose a major challenge to the provision of health, education and other services. Some of the smaller countries have much lower growth rates-in some, reflecting outward migration to countries such as Australia and New Zealand.

The leading causes of child mortality in the lowincome countries in the region are communicable diseases: pneumonia, meningitis, diarrhoeal disease, malaria and, in some of the countries, tuberculosis (TB). Many deaths can be avoided with simple preventative and curative interventions. EPI programmes (immunisation programmes) are well established in all countries, but achieving high vaccination coverage has proved difficult in some. In several of the countries, fewer than $75 \%$ of children are protected by DPT3 (third dose of diphtheria, tetanus and pertussis vaccine, either as 'triple vaccine' or incorporated into other multiantigen vaccines), and, although routine measlescontaining vaccine coverage at the 95\% level required has been reached in a few countries including Fiji and Samoa, it is well below this in 


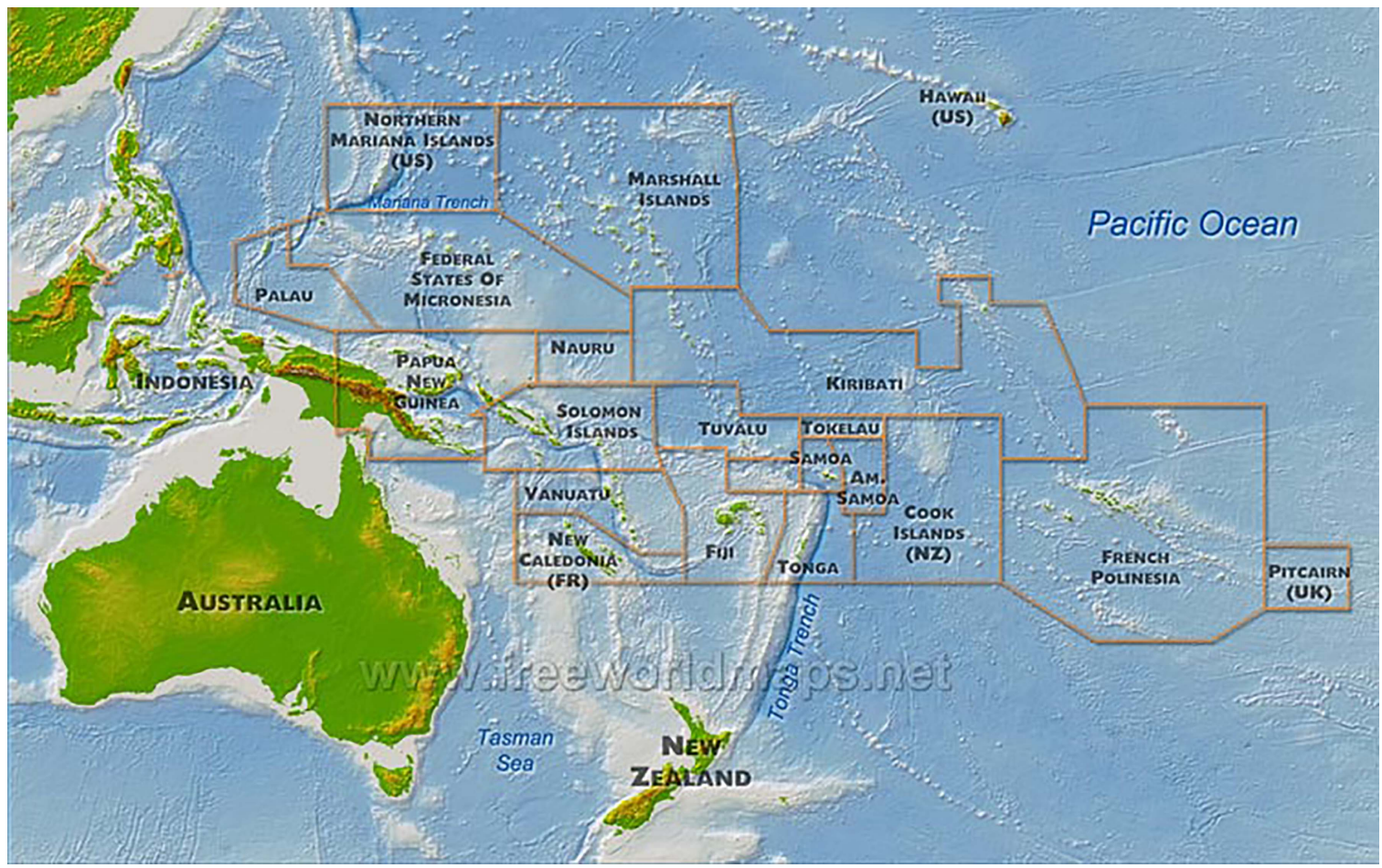

Figure 1 Map of Oceania (Timor Leste not marked). Cartographer: Daniel Feher. http://www.freeworldmaps.net/oceania/

several others. Conjugate Haemophilus influenza type b vaccine has been introduced to all the countries, but pneumococcal conjugate vaccines, which have been part of the programme in Australia and New Zealand for some years, have yet to be introduced in most of the Pacific Island countries.

Safe water supplies are still not available for many communities, and the understanding of the importance of hygiene practices is limited in some population groups.

TB is a significant problem in several of the region's countries, with prevalences ranging from 1.7/100 000 in Fiji to 541/ 100/000 in PNG. ${ }^{4}$ Mortality rates from TB in children are not easy to find, but, in high-prevalence countries, TB is a significant cause of death. In PNG hospitals, TB accounts for between 7\% and $8 \%$ of admissions to the children's wards, has disproportionately high bed occupancy, and carries a case fatality of $13 \%$. Multidrug-resistant TB is well established in PNG, presenting additional challenges.

Malnutrition is a significant problem in some of the Oceania countries, with undernutrition estimated to affect $18 \%$ of children in PNG, 12\% in Solomon Islands and 11\% in Vanuatu. As elsewhere in the world, malnutrition contributes both directly and indirectly to mortality.

Table 1 Mortality rates and related indices in some Oceania countries

\begin{tabular}{|c|c|c|c|c|c|c|c|c|c|c|c|c|c|}
\hline \multirow{2}{*}{$\begin{array}{l}\text { Rank } \\
\text { by } \\
\text { U5MR }\end{array}$} & \multirow[b]{2}{*}{ Country } & \multicolumn{2}{|l|}{ U5MR } & \multicolumn{2}{|c|}{$\begin{array}{l}\text { Infant } \\
\text { mortality }\end{array}$} & \multirow{2}{*}{$\begin{array}{l}\text { Neonatal } \\
\text { mortality } \\
2012\end{array}$} & \multirow{2}{*}{$\begin{array}{l}\text { \% change } \\
\text { in } \\
\text { U5MR } \\
\text { since } 1990\end{array}$} & \multirow{2}{*}{$\begin{array}{l}\text { Adjusted } \\
\text { maternal } \\
\text { mortality } \\
\text { rate } 2010\end{array}$} & \multirow[b]{2}{*}{$\begin{array}{l}\text { Population } \\
\text { (1000 s) }\end{array}$} & \multirow{2}{*}{$\begin{array}{l}\text { GNI } \\
\text { per } \\
\text { capita } \\
\text { (US\$) }\end{array}$} & \multicolumn{2}{|c|}{$\begin{array}{l}\text { Education } \\
\text { status }\end{array}$} & \multirow{2}{*}{$\begin{array}{l}\text { Human } \\
\text { development } \\
\text { index }\end{array}$} \\
\hline & & 1990 & 2012 & 1990 & 2012 & & & & & & ALR & $\begin{array}{l}1^{0} \\
\text { enrol }\end{array}$ & \\
\hline 41 & $\begin{array}{l}\text { Papua New } \\
\text { Guinea }\end{array}$ & 89 & 63 & 65 & 48 & 24 & 29 & $230 *$ & 7167 & 1790 & 62 & & 0.466 \\
\hline 43 & Kiribati & 94 & 60 & 68 & 46 & 22 & 36 & & 101 & 2260 & & & 0.629 \\
\hline 48 & Timor Leste & 171 & 57 & 129 & 48 & 24 & 67 & 300 & 1114 & 3670 & 58 & 91 & 0.576 \\
\hline 66 & Marshall islands & 49 & 38 & 39 & 31 & 16 & 23 & $140^{+}$ & 53 & 4140 & & 99 & \\
\hline 72 & Solomon Islands & 39 & 31 & 31 & 26 & 14 & 19 & 93 & 550 & 1130 & & 88 & 0.53 \\
\hline 88 & Fiji & 31 & 22 & 26 & 19 & 10 & 27 & 26 & 875 & 4200 & & 99 & 0.702 \\
\hline 100 & Vanuatu & 35 & 18 & 29 & 15 & 9 & 48 & 110 & 247 & 3080 & 83 & & 0.626 \\
\hline 100 & Samoa & 30 & 18 & 25 & 15 & 7 & 41 & 100 & 189 & 3220 & 99 & 93 & 0.702 \\
\hline 125 & Tonga & 23 & 13 & 20 & 11 & 7 & 44 & 110 & 105 & 4240 & 90 & & 0.71 \\
\hline 157 & New Zealand & 11 & 6 & 9 & 5 & 3 & 49 & 15 & 4460 & 30620 & & 99 & 0.919 \\
\hline 161 & Australia. & 9 & 5 & 8 & 4 & 3 & 47 & 7 & 23050 & 59570 & & 97 & 0.938 \\
\hline
\end{tabular}

Data from Unicef State of the World's Children Report (2014) and United Nations Development Programme Human Development Report (2013).

*Probably higher. DHS survey of 2006 reported a figure of $730 / 100000$.

${ }^{+}$Reported rate 2008-2012.

$1^{0}$, primary school; ALR, adult literacy rate; GNI, gross national income; U5MR, under 5 mortality rate. 
Countries in the Oceania region report low prevalences of HIV. PNG has a reported prevalence of $0.5 \%$ in the reproductive age group, and HIV accounted for $6.3 \%$ of the deaths in the paediatric ward at Port Moresby General Hospital in 2013.

While some of the countries in the region have reached or may well reach the MDG target, others have a long way to go. However, it is important to appreciate that progress has been made in all of the countries-often in spite of formidable constraints. ${ }^{5}$ The introduction and tighter control of the use of effective artemether combination antimalarials in malariaaffected countries and the introduction of insecticide-treated bed nets has led to a reduction in malarial morbidity and mortality. The introduction and appropriate use of oxygen concentrators for provision of oxygen has significantly reduced mortality in children with pneumonia and other severe illnesses. Some countries have well-established child health policies and strategic implementation plans, focusing on common problems and achievable goals. Many countries are focusing attention on reduction of neonatal mortality by simple and practical means. However, for some of the Oceania region countries, there are clear deficiencies in the provision of primary healthcare, and further progress will come not from focusing on sophisticated hospital care but simply by getting the basics of disease prevention and adequate management of the common illnesses right. A functioning heath system that is adequately funded, equipped and staffed will form the basis for continuing progress, but the wider aspects of health-such as education and infrastructure development-are of equal importance.
There are many challenges to continuing progress in many of the Oceania countries. These include dealing with the unmet need for family planning to slow the population growth rate, planning for the effects of climate change (being felt most acutely in the pacific atolls), and ensuring the rights of women, children and disadvantaged communities. Much will depend on the quality and the ability of governance at all levels to ensure equitable distribution of resources and sustainable development, and to minimise damaging environmental and social effects of mineral, petroleum, gas, forestry and other industries.

Paediatricians in the Oceania region have demonstrated commitment to child health in the widest sense-and it is imperative that they continue to do so.

Acknowledgements I am grateful to Professor Trevor Duke of the Centre for International Child Health, University of Melbourne for his helpful comments.

Competing interests None.

Provenance and peer review Commissioned; externally peer reviewed.

\section{REFERENCES}

1 State of the World's Children 2014. Basic Indicators Tables 1, Nutrition Table 2, Economic Indicators Table 7, Women Table 8 and Rate of Progress Table 10. Unicef New York. http://www.unicef.org/sowc2014/numbers/

2 United Nations Development Programme Human Development Report. 2013. http:// hdr.undp.org/en/content/human-development-report-2013

3 Australian Bureau of Statistics 3302.0-Deaths, Australia, 2012. http://www.abs.gov. au/ausstats/abs@.nsf/mf/3302.0/

4 Tuberculosis Country Profiles. WHO Geneva. http://www.who.int/tb/country/en/

5 Lagani W, Mokela D, Oswyn G, et al. Papua New Guinea: real progress towards MDG-4 and real challenges. Int Health 2010;2:186-96. 


\section{ADC Millennium Development Goals: progress in Oceania}

John D Vince

Arch Dis Child 2015 100: S63-S65

doi: 10.1136/archdischild-2013-305618

Updated information and services can be found at:

http://adc.bmj.com/content/100/Suppl_1/S63

These include:

References This article cites 1 articles, 0 of which you can access for free at: http://adc.bmj.com/content/100/Suppl_1/S63\#BIBL

Email alerting Receive free email alerts when new articles cite this article. Sign up in the service box at the top right corner of the online article.

Collections

Articles on similar topics can be found in the following collections

Epidemiologic studies (1818)

Injury (437)

Trauma (434)

\section{Notes}

To request permissions go to:

http://group.bmj.com/group/rights-licensing/permissions

To order reprints go to:

http://journals.bmj.com/cgi/reprintform

To subscribe to BMJ go to:

http://group.bmj.com/subscribe/ 